\title{
IMPACT OF SOIL TILLAGE INTENSITY ON FABA BEAN CULTIVATION
}

\author{
Kestutis Romaneckas, Rasa Kimbirauskiene, Aida Adamaviciene, Algirdas Jasinskas, Egidijus Sarauskis \\ Aleksandras Stulginskis University, Lithuania \\ kestas.romaneckas@asu.lt, , algirdas.jasinskas@asu.lt
}

\begin{abstract}
Since 2015, the EU Greening program requested increasing the area of leguminous crops. Lithuanian conditions are the most favorable for pea and faba bean cultivation. Therefore, the area of these crops increased several times. Unfortunately, there is no precise scientific background of faba bean growing technologies in Lithuania. For this reason, a stationary field experiment was performed in Aleksandras Stulginskis University, Lithuania. The soil in the experiment was light loam (Endohypogleyic-Eutric Planosol, PLe-gln-w). The climate of the experimental site is subarctic, with wet winters and moderate summers. The long-term (60 years) average annual precipitation rate is $625.5 \mathrm{~mm}$. Faba bean crop was grown in differently tilled soil: deeply $(22-25 \mathrm{~cm})$ and shallowly $(12-15 \mathrm{~cm})$ ploughed with a moldboard plough, deeply $(25-30 \mathrm{~cm})$ cultivated with a chisel cultivator, shallowly $(10-12 \mathrm{~cm})$ tilled with a disc harrow and no tilled (direct drilling). The aim of the experiment was to investigate the influence of five reduced tillage patterns on the parameters of faba bean cultivation. The results from the 2016 vegetative period are presented. According to the results of investigations, reduction of primary tillage intensity from conventional deep ploughing to no-till (direct drilling) mainly had no essential impact on productivity potential of faba bean cultivation. The density of crop was a key parameter, which effected variance between the treatments.
\end{abstract}

Key words: faba bean cultivation, productivity, tillage intensity.

\section{Introduction}

Recently, both in our country and abroad, a lot of attention is paid to reduction of soil tillage (minimization). Minimization of tillage is the reduction of energy costs by reducing the number and depth of tillage, combining tillage processes into one, and reducing the working surface. Minimization of tillage increases labour productivity, reduces costs, increases soil fertility, protects it from unnecessary compression by tractors and agricultural machinery, and improves the balance of soil water, nutrients and organic matter [1-5]. The aim of tillage minimizing (reduction) is not only to reduce production costs but also to maintain potentially fertile soils for the longer [6]. Deep ploughing is one of the most expensive tillage operations because it requires high labour and fuel consumption, one of the most fertile layer replacing tillage technological processes [7-8]. However, weedy soils require intensive deep ploughing [9].

Experiments in Romania showed that shallow ploughing $(10 \mathrm{~cm}$ depth) initiated better results than the deep $(20 \mathrm{~cm})$. While ploughed deeply, favourable for crop growing water, air and nutrition mode is formed in a thicker soil layer. During the dry period, in deeply ploughed soils, moisture is maintained for longer. In humid - the surplus water is deposited in the broom of arable layer and become less harmful for the crop roots. In addition, in deeply ploughed soil, the roots of the plant penetrate deeper and provide better nutrient supplies, improve air circulation in the deeper layers. In deep ploughed soils there is less weed infestation [10]. According to P. Vasinauskas [11], deep ploughing is like an amelioration tool, which, after several years of use, after deep ploughing of soil, can be done in a shallow way.

The experiments carried out in Dotnuva (Lithuanian Institute of Agriculture) showed that the minimization of tillage in loam soils depends on its acculturation degree. In the well-cultured light loam soils, deep ploughing can be simplified and change deep ploughing (22-25 depth) to deep cultivation (20-25 cm depth) in combination with shallow stubble loosening. For example, replacing deep ploughing to deep cultivation had not a significant decrease in the yield of sugar beet [10;12]. In Munoz-Romero investigations [13], no tillage was more favourable for the development of the faba bean root system than conventional. This can improve the soil physical properties and the yield. Similarly, Volpi et al. [14] found that minimum tillage might be more suitable than ploughing in Italian Mediterranean climate conditions, because faba bean grain yield increases and reduces cumulative $\mathrm{N}_{2} \mathrm{O}$ emissions by up to $80 \%$.

In Lithuania, impact of long-term reduced tillage systems on faba bean productivity and grain quality were not investigated at all. So, the aim of our study was to establish the impact of low- 
intensity tillage systems on faba bean productivity and quality parameters in long-term tillage reducing experiment.

\section{Materials and methods}

A stationary long-term field experiment has been conducted at the Aleksandras Stulginskis University (ASU) Experimental Station $\left(54^{\circ} 52^{\prime} \mathrm{N}, 23^{\circ} 49^{\prime} \mathrm{E}\right)$ in Lithuania since 1988. In this study, the data of 2016 are presented. Experimental soil is a silty loam (45.6\% sand, $41.7 \%$ silt, $12.7 \%$ clay) Planosol (Endohypogleyic-Eutric - Ple-gln-w) [15]. The soil of the experiment is neutral, rich of phosphorus, magnesium and with average amount of potassium.

Meteorological conditions during the faba bean vegetation are presented in Tables 1 and 2. In 2016, the beginning of faba bean vegetation was warmer than usually and the end - little colder. Precipitation rate mainly was higher than long-term average, especially at the second part of vegetation.

Table 1

Average air temperature ${ }^{\circ} \mathrm{C}$ during 2016 vegetation. Kaunas Meteorological Station

\begin{tabular}{|c|c|c|c|c|c|}
\hline \multirow{2}{*}{ Months } & \multicolumn{3}{|c|}{ 10 days period } & \multirow{2}{*}{ Monthly } & $\begin{array}{c}\text { Long-term (1974-2013) } \\
\text { average }\end{array}$ \\
\cline { 2 - 4 } & I & II & III & & 6.9 \\
\hline April & 8.4 & 7.8 & 6.1 & 7.4 & 13.2 \\
\hline May & 16.8 & 12.6 & 17.9 & 15.7 & 16.1 \\
\hline June & 15.9 & 15.4 & 20.3 & 17.2 & 18.7 \\
\hline July & 16.6 & 17.2 & 19.9 & 17.9 & 17.3 \\
\hline August & 17.7 & 15.0 & 18.0 & 16.9 & \\
\hline
\end{tabular}

Table 2

Precipitation rate mm during 2016 vegetation. Kaunas Meteorological Station

\begin{tabular}{|c|c|c|c|c|c|}
\hline \multirow{2}{*}{ Months } & \multicolumn{3}{|c|}{ 10 days period } & \multirow{2}{*}{ Monthly } & $\begin{array}{c}\text { Long-term (1974-2013) } \\
\text { average }\end{array}$ \\
\cline { 2 - 4 } & I & II & III & & 41.3 \\
\hline April & 3.3 & 26.4 & 11.5 & 41.2 & 61.7 \\
\hline May & 4.7 & 31.3 & 0.4 & 36.4 & 76.9 \\
\hline June & 11.4 & 58.5 & 14.0 & 83.9 & 96.6 \\
\hline July & 77.7 & 40.8 & 44.4 & 162.9 & 88.9 \\
\hline August & 45.8 & 29.9 & 39.2 & 114.9 & \\
\hline
\end{tabular}

In our experiment, five soil tillage systems of different intensity were investigated: 1) conventional deep $(22-25 \mathrm{~cm})$ ploughing $(\mathrm{CP}) ; 2)$ shallow $(12-15 \mathrm{~cm})$ ploughing $(\mathrm{SP}) ; 3)$ deep $(25$ $30 \mathrm{~cm}$ ) cultivation (chiselling) (DC); 4) shallow $(10-12 \mathrm{~cm}$ ) cultivation (disking) (SC); 5) no-till (direct sowing) (NT). The experiment was designed with four replications and randomized distribution of treatments. The initial size of the experimental plot was $70 \mathrm{~m}^{2}$, total number of plots -20 . The precrop of faba bean was winter wheat. Agrotechnical practice of the experiment is presented in Table 3.

Table 3

Agrotechnical practice in the experiment

\begin{tabular}{|c|c|}
\hline Agrotechnical operation & $\begin{array}{c}\text { Time of operation } \\
\text { (day/month) }\end{array}$ \\
\hline Herbicide "Glyphogan" application (only in NT plots, 4 1·ha' $\left.{ }^{-1}\right)$ & $06 / 04$ \\
\hline Soil surface tillage & $21 / 04$ \\
\hline Pre-sowing soil tillage & $25 / 04$ \\
\hline Fertilization NPK 7:16:32 (300 kg.ha $\left.{ }^{-1}\right)$ during sowing operation & $25 / 04$ \\
\hline Sowing & $25 / 04$ \\
\hline Herbicide "Fenix" application $\left(31 \cdot \mathrm{ha}^{-1}\right)$ & $26 / 04$ \\
\hline Insecticide "Karate" application $\left(0.15 \mathrm{~kg}^{-1} \mathrm{ha}^{-1}\right)$ & $10 / 05$ \\
\hline Fungicide "Signum" application $\left(1 \mathrm{l} \cdot \mathrm{ha}^{-1}\right)$ & $13 / 06$ \\
\hline Harvesting & $09 / 09$ \\
\hline
\end{tabular}


The soil was tilled in the autumn, October. The CP and SP plots were ploughed with a Gamega PP-3-43 plough with semi-helical shellboards, DC - with a chisel cultivator KRG-3.6, and the SC with a disc harrow Väderstad Carrier 300. Pre-sowing tillage was executed with a complex cultivator Laumetris KLG-3.6. The sowing machine Väderstad Rapid 300C Super XL was used for sowing. The distance between the rows was $25 \mathrm{~cm}$, sowing rate $-200 \mathrm{~kg}$ grain per ha, sowing depth $-5-6 \mathrm{~cm}$. Variety "Fuego" was applied. Detailed explanation of faba bean agro-technic in the experiment could be found in our earlier publication [16]. Yield of faba bean grain was harvested with a plot combine Winterstager Delta.

The experimental data were statistically tested by using the one-way analysis of variance (ANOVA) with program package "Selekcija" and "Irristat" for processing statistical data [17]. The trial data were also evaluated using the correlation analysis by "SigmaStat" and "SigmaPlot" softwares. Significant differences between treatments of the experiments and the control treatment are expressed by: $*$ - significant difference at the $95 \%$ probability level $(P \leq 0.05>0.01)$; ** significant difference at the $99 \%$ probability level $(P \leq 0.01>0.001) ; P>0.05-$ no significant difference at the $95 \%$ probability level.

\section{Results and discussion}

In our experiment, in shallowly cultivated soil faba beans grew significantly sparser than in deeply ploughed (Table 4). In deeply ploughed soil the stand of beans was the densest -55.6 psc. per $\mathrm{m}^{2}$.

The lower density of faba bean crop in shallowly cultivated plots initiated the significant decrease of the number of pods per square meter of crop (Table 4). Here were found on average $338 \mathrm{pcs}$. of pods per $\mathrm{m}^{2}$. We found a strong significant relationship between the crop density per $\mathrm{m}^{2}$ and the number of pods $(r=0.901 *)$.

In our previous investigations of soil tillage systems, the reduction of annual deep ploughing to non-invertible tillage or even direct sowing to untilled soils did not have a significant negative effect on the productivity of sugar beet and maize [12; 18-19].

In the presented experiment, in 2016, tillage systems of different intensity also did not have a significant effect on the yield of faba bean grain (Table 4). The harvested grain yield varied from 4.04 to $4.95 \mathrm{t} \mathrm{ha}^{-1}$. Despite this, the largest grain yield was obtained from the deeply ploughed plots beans growing deep in the fields in the autumn, and the smallest - in shallowly cultivated. Grain productivity was largely influenced by differences in the crop density $\left(r=0.946^{*}\right)$ and the number of pods per $\mathrm{m}^{2}$ $\left(r=0.950^{*}\right)$.

Lower crop density in shallowly cultivated plots affected the formation of larger grain $(r=-0.454)$. The mass of 1000 grain reached $610.17 \mathrm{~g}$, but was not significantly higher than in other treatments (Table 4). It should be noted that meteorological conditions in 2016 vegetation were not very favourable for faba bean development, so the size and mass of grain were less than in the research station tests.

Table 4

Faba bean productivity and quality parameters

\begin{tabular}{|c|c|c|c|c|c|}
\hline Tillage system & $\begin{array}{c}\text { Number of } \\
\text { plants per } \\
\mathbf{m}^{\mathbf{2}}\end{array}$ & $\begin{array}{c}\text { Number of } \\
\mathbf{p o d s} \mathbf{~ p e r} \\
\mathbf{m}^{\mathbf{2}}\end{array}$ & $\begin{array}{c}\text { Yield of } \\
\text { grain, } \\
\mathbf{t} \cdot \mathbf{h a}^{-\mathbf{1}}\end{array}$ & $\begin{array}{c}\text { Mass of } \\
\mathbf{1 0 0 0} \text { grain, } \\
\mathbf{g}\end{array}$ & $\begin{array}{c}\text { Protein } \\
\text { content, \% }\end{array}$ \\
\hline Conventional ploughing & 55.6 & 399.6 & 4.95 & 594.22 & 28.27 \\
\hline Shallow ploughing & 50.4 & 370.4 & 4.33 & 599.92 & 29.00 \\
\hline Deep cultivation & 50.8 & 369.2 & 4.55 & 576.04 & 28.75 \\
\hline Shallow cultivation & $46.4^{*}$ & $338.0^{*}$ & 4.04 & 610.17 & 27.82 \\
\hline No-till & 51.6 & 352.8 & 4.35 & 583.94 & 29.06 \\
\hline
\end{tabular}

Note: $*$ - significant differences from control treatment (conventional ploughing) at $95 \%$ probability level. 
The highest grain protein content was determined in beans grown under untreated conditions (NT) (Table 4). It reached $29.06 \%$. The lowest - in shallowly cultivated plots $(27.82 \%)$. The differences were not significant.

\section{Conclusions}

1. Different tillage systems did not have a significant effect on the mass of 1000 grain, grain yield and protein content.

2. The largest number of pods (399.6 units per $\mathrm{m}^{2}$ ) was grown in conventionally ploughed soil or significantly (about 60 units per $\mathrm{m}^{2}$ ) more than in shallowly ploughed.

3. Low-intensity tillage treatments are the right practice for faba bean cultivation in the case of economic and environmental sustainability. Investigations should be continued.

\section{Acknowledgement}

This research was funded by a grant (№ MT-16-8) from the Lithuanian Ministry of Agriculture.

\section{References}

[1] Riley H., Ekeberg E., Borresen T. Long term field experiments with reduced tillage in Norway. Proceedings of NJF seminar "Soil tillage and biology", vol. 286. Norway. 1998.

[2] Šimanskaitė D., Feiza V., Lazauskas S. etc. Soil tillage systems impact hydrophysical properties of gleyic Cambisol. Zemdirbyste - Agriculture, vol. 96(1), 2009, pp. 23-38.

[3] Morris N.L., Miller P.C.H., Orson J. H. ect. The adoption of non-inversion tillage systems in the United Kingdom and the agronomic impact on soil, crops and the environment - a review. Soil and Tillage Research, vol. 108(1), 2010, pp. 1-15.

[4] Lozano-García B., Parras-Alcántara L. Changes in soil properties and soil solution nutrients due to conservation versus conventional tillage in Vertisols. Archives of Agronomy and Soil Science, val. 60(10), 2014, pp. 1429-1444.

[5] Šarauskis E., Buragiene S., Masilionyte L., Romaneckas K. etc. Energy balance, costs and CO2 analysis of tillage technologies in maize cultivation. Energy, vol. 69, 2014, pp. 227-235.

[6] Tindžiulis A. Žemès dirbimas (Soil tillage). Vilnius: Mokslas, 1979. (in Lithuanian).

[7] Arlauskas M. Minimalus žemės dirbimas (Minimal soil tillage). Dotnuva-Akademija, 1994. (In Lithuanian).

[8] Šarauskis E., Masilionyte L., Andriusis A. etc. The force needed for breaking and cutting of winter wheat and spring barley straw. Zemdirbyste-Agriculture, vol. 100(3), 2013, pp. 269-276.

[9] Stancevičius A., Jodaugienè D., Špokienè N. etc. The effect of ploughing and ploughless soil tillage on soil physical properties and crop productivity. Žemdirbystè, vol. 83(3), 2003, pp. 40-51.

[10] Šimanskaite D., Svirskienè A. The possibilities to reduce primary soil tillage in light loam soils. Akademija: LŽŪU. 1999. (in Lithuanian with English summary).

[11] Vasinauskas P. Lietuvos žemès ūkio plètra (Development of Lithuanian agriculture). Vilnius: Mokslas. 1986. (in Lithuanian).

[12] Romaneckas K., Romaneckienè R., Šarauskis E. The effect of primary soil tillage methods on sugar beet growth on a light loam luvisol. Zemdirbyste-Agriculture, vol. 93(4), 2006, pp. 81-87.

[13] Munoz-Romero V., López-Bellido L., López-Bellido R. J. Faba bean root growth in a Vertisol: Tillage effects. Field Crops Research, vol. 120, 2011, pp. 338-344.

[14] Volpi I., Antichi D., Ambus P. L., Bonari E., o Di Nasso N. N., Bosco S. Minimum tillage mitigated soil $\mathrm{N} 2 \mathrm{O}$ emissions and maximized crop yield in faba bean in a Mediterranean environment. Soil \& Tillage Research, vol. 178, 2018, pp. 11-21.

[15] World reference base for soil resources (WRB) International soil classification system for naming soils and creating legends for soil maps. World Soil Resources Reports No. 106. Rome: FAO. 2014.

[16] Romaneckas K., Adamavičienė A., Sinkevičienė A. etc. Influence of five tillage patterns on faba bean productivity parameters. Proceedings of the 45 International Symposium on Agricultural Engineering "Actual Tasks on Agricultural Engineering”. Opatija, Croatia, 21-24 February, 2017, pp. 183-190. 
[17] Tarakanovas P., Raudonius S. Agronominių tyrimų duomenų statistinė analizė taikant kompiuterines programas ANOVA, STAT, SPLIT-PLOT iš paketo SELEKCIJA ir IRRISTAT (The program package "SELEKCIJA" and "IRRISTAT" for processing statistical data. Akademija-Kedainiai, 2003. (in Lithuanian).

[18] Romaneckas K., Romaneckienė R., Šarauskis E. etc. The effect of conservation primary and zero tillage on soil bulk density, water content, sugar beet growth and weed infestation. Agronomy Research, vol. 7(1), 2009, pp. 73-86.

[19] Avižienytė D. Impact of long-term different soil tillage on agrocenosis in conditions of intensive agriculture and crop rotation. Summary of doctoral dissertation. Kaunas: ASU, 2013. 